\title{
Comparative environmental impacts of intensive all-grass and maize silage-supplemented dairy farm systems: a review
}

\author{
I.D. WILLIAMS ${ }^{1}$, S.F. LEDGARD ${ }^{2}$, G.O. EDMEADES ${ }^{3}$ and R.J. DENSLEY ${ }^{1}$ \\ ${ }^{I}$ Genetic Technologies Ltd., P.O. Box 105 303, Auckland \\ ${ }^{2}$ AgResearch, Ruakura Research Centre, Private Bag 3123, Hamilton \\ ${ }^{3} 43$ Hemans St., Cambridge \\ iwilliams@genetic.co.nz
}

\begin{abstract}
New Zealand dairy farmers are lifting stocking rates and increasing available feed through nitrogen $(\mathrm{N})$ fertiliser applications to pasture, growing maize for silage and other supplementary crops for silage or grazing on-farm, and/or procuring feed supplements off-farm. This has raised concerns about the possibility of increased risk of nutrient losses to waterways and the atmosphere. This paper reviews NZ and overseas data on the integration of maize silage into dairy systems. Maize silage is a low protein forage which helps optimise animal protein intake and reduces $\mathrm{N}$ loss. Maize silage-supplemented dairy farms leached more nitrogen per hectare but less per $\mathrm{kg}$ milksolids (MS) than intensive all-grass systems. Feeding maize silage on a feedpad and spreading the resulting effluent uniformly over the farm further reduces $\mathrm{N}$ leaching. In the Resource Efficient Dairying (RED) trial, total emissions of nitrous oxide $\left(\mathrm{N}_{2} \mathrm{O}\right.$, a potent greenhouse gas) for the maize-supplemented farmlet was $14 \%$ lower on a per hectare basis and $22 \%$ lower on a $\mathrm{kg}$ MS basis than the all-grass system when both received $170 \mathrm{~kg} \mathrm{~N} / \mathrm{ha}$ as urea. The increases in maize dry matter production in response to incremental additions of $\mathrm{N}$ and water, where production is constrained by these inputs, can be 2-3 times greater than that for pasture. Using a feed and stand-off pad and managing maize growing through minimising tillage effects, determining soil $\mathrm{N}$ status at planting and timing $\mathrm{N}$ applications appropriately further reduce the environmental impact of maize silage-based dairy systems.
\end{abstract}

Keywords: all-grass, environment, greenhouse gases, intensive dairy systems, maize silage, nitrates

\section{Introduction}

There is increasing pressure on New Zealand's dairy farmers to intensify production so that they can maintain or increase returns from land, which is by far their largest on-farm capital item. Fonterra's goal of a 3\% annual increase in dairy production greatly exceeds the annual increase in pasture production through introduction of improved varieties (Easton et al. 2002). Thus, in order to increase milk production per hectare, farmers are increasing stocking rates, augmenting available feed through nitrogen $(\mathrm{N})$ applications to pasture, growing maize and other supplementary crops for silage or grazing on-farm, and/or procuring feed supplements off-farm (Hedley et al. 2006). This has increased the rate of nutrient cycling through the soil-plant-animal system, and raised concerns about the impact of nutrient losses to waterways (Ledgard \& Menneer 2005) and the atmosphere (Luo et al. 2006).

There are two ways to evaluate the environmental impact of intensifying dairy systems. Losses of nutrients per hectare are important when the primary concern is contamination of catchments, since the absorptive capacity of soil and atmosphere is limited. Loss per unit of production (e.g. per kg milksolids (MS)) is suitable for comparing the environmental impact of productivity increases when the absorptive capacity of the environment for nutrients is still well below a critical threshold. Both approaches have their uses (Ledgard et al. 2006b). N and water use efficiencies (NUE; WUE) are also measures of output (e.g. $\mathrm{kg} \mathrm{DM} / \mathrm{ha}$ ) per unit of input (e.g. $\mathrm{kg} \mathrm{DM} / \mathrm{kg} \mathrm{N}$ applied; $\mathrm{kg} \mathrm{DM} / \mathrm{mm}$ water applied). These provide useful bases for comparisons since $\mathrm{N}$ is the source of nitrate contamination of ground water, and water is likely to limit agricultural production in New Zealand as global warming proceeds.

While there are theoretical data to suggest that carbon dioxide $\left(\mathrm{CO}_{2}\right)$ equivalents per $\mathrm{kg}$ MS are higher for a total mixed ration (TMR) dairy system that includes maize silage compared with an average Waikato all-grass farm producing a relatively modest $899 \mathrm{~kg} \mathrm{MS} / \mathrm{ha}$ (van der Nagel et al. 2003), there is no published information comparing intensive all-grass with maize silagesupplemented dairy systems. Feeding TMR decreased methane production but increased $\mathrm{CO}_{2}$ emissions from inputs (including machinery) and cultivation (van der Nagel et al. 2003). Cultivation carbon losses can be substantially reduced by changing from traditional tillage techniques to strip till or no-till (Reicosky 2001).

We have focused on $\mathrm{N}$ rather than $\mathrm{CO}_{2}$ in this discussion because nitrous oxide $\left(\mathrm{N}_{2} \mathrm{O}\right)$ has 310 times the global warming potential of $\mathrm{CO}_{2}$ (EPA, 2007).

Environmental indicators such as greenhouse gas emissions and $\mathrm{N}$ leaching have been evaluated in long term Resource Efficient Dairying (RED) trials at Dexcel, Hamilton, based on farmlets that varied in stocking 
Table 1 Effect of feed source on $\mathrm{N}$ output in milk, dung and urine in absolute and relative terms (Ledgard 2006).

\begin{tabular}{lcccc}
\hline Type of silage & $\begin{array}{c}\mathrm{N} \text { intake } \\
(\mathrm{kg} \mathrm{N} / \mathrm{cow})\end{array}$ & Milk & $\begin{array}{c}\text { N output (kg N/cow) (\% intake) } \\
\text { Dung }\end{array}$ & Urine \\
\hline Lucerne & 37 & $6(16)$ & $8(22)$ & $23(62)$ \\
Pasture & 24 & $6(25)$ & $7(29)$ & $11(46)$ \\
Cereal & 16 & $6(38)$ & $5(31)$ & $5(31)$ \\
Maize & 12 & $6(50)$ & $3(25)$ & $3(25)$ \\
\hline
\end{tabular}

${ }^{a}$ Based on $1 \mathrm{t} \mathrm{DM} / \mathrm{cow}$

intensity, input use and level of supplementary feed (Jensen et al. 2005; Ledgard et al. 2006a). Information from these trials provides a basis for much of the review in this paper in which we compare the environmental impacts of intensive all-grass dairy systems and pasture based systems supplemented with maize silage. We discuss ways to manage both systems for increased output and reduced environmental impact.

\section{Environmental impact and resource use efficiency of intensive all-grass dairy systems Nitrogen losses}

Relying solely on $\mathrm{N}$ fertiliser applications to increase the feed supply from pasture results in forage with $\mathrm{N}$ levels exceeding the requirements of lactating cows (Hoekstra et al. 2007). This causes a high proportion (typically about $60-70 \%$ ) of $\mathrm{N}$ intake to be excreted in urine (Table 1).

Cows urinate at random on pasture as they graze and the $\mathrm{N}$ deposit under each urine patch may exceed 1000 $\mathrm{kg} \mathrm{N} / \mathrm{ha}$, resulting in the risk of significant leaching of nitrates.
Predicted and measured rates of leaching in the RED trial (Fig. 1) show that typical losses beneath Waikato pasture receiving $170 \mathrm{~kg}$ fertiliser $\mathrm{N} / \mathrm{ha} / \mathrm{yr}$ and having an $\mathrm{N}$ surplus of $189 \mathrm{~kg} \mathrm{~N} / \mathrm{ha} / \mathrm{yr}$ are $40-50 \mathrm{~kg} \mathrm{~N} / \mathrm{ha} / \mathrm{yr}$ (Ledgard et al. 2006a). This equated to an average loss of $39 \mathrm{~kg} \mathrm{~N} / \mathrm{t}$ MS under pasture receiving $170 \mathrm{~kg} \mathrm{~N} / \mathrm{ha}$. This was $60 \%$ higher than a zero $\mathrm{N}$ treatment, and the loss dropped to $29 \mathrm{~kg} \mathrm{~N} / \mathrm{t}$ MS when a stand-off area was used to collect effluent during winter.

A further loss of $\mathrm{N}$ is through denitrification that leads to the formation of $\mathrm{N}_{2} \mathrm{O}$. This typically occurs under pastures when the water filled pore space increases in the autumn, winter and early spring, and has averaged $0.82 \%$ of $\mathrm{N}$ applied as urea (Luo et al. 2005). Losses are exacerbated by pugging in winter.

\section{Nitrogen use efficiency}

Pasture production increases in response to $\mathrm{N}$ application, typically at the rate of $15-35 \mathrm{~kg} \mathrm{DM} / \mathrm{kg} \mathrm{N}$ for the first $50 \mathrm{~kg} \mathrm{~N}$ applied (Quin et al. 2005). Average responses to applying $170-210 \mathrm{~kg} \mathrm{~N} / \mathrm{ha}$ to pasture as urea have been 15-17 kg DM/kg N (Harris et al. 1996;

Figure 1 Nitrogen leaching losses from RED farmlets alone, and the farmlet plus the area used to rear replacements or grow maize silage (based on Ledgard et al. 2006a). Dotted bars in the maize farmlets assume optimum maize management to halve measured $\mathrm{N}$ leaching in the maize growing areas.

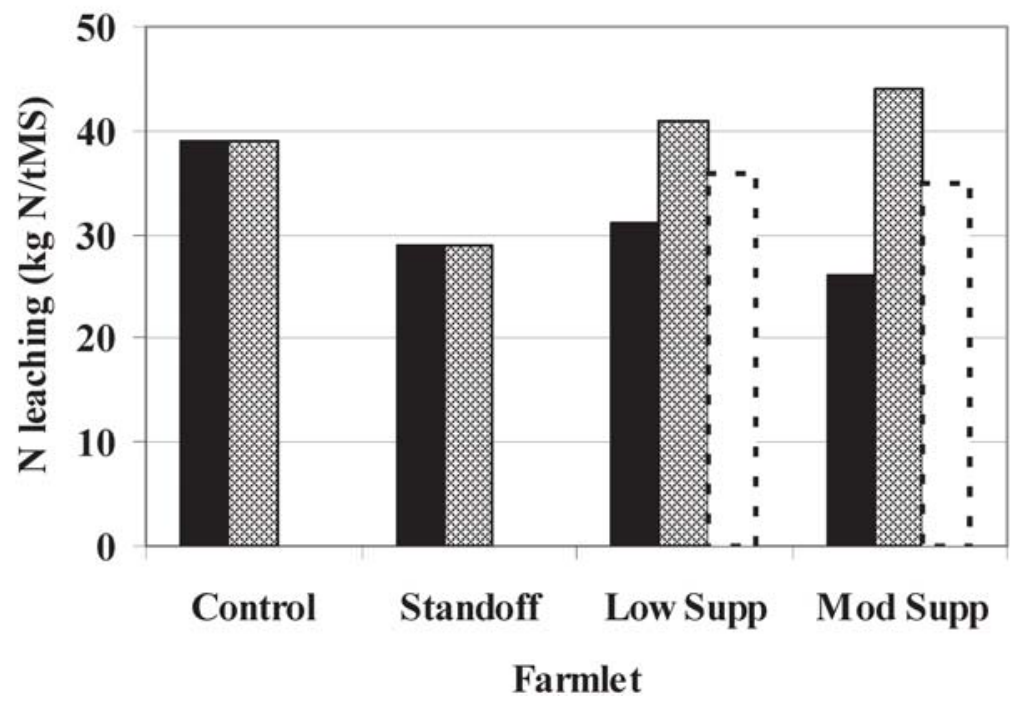

- Farmlet

图 Total Area

i. Opt. Mgt 
Table 2 Performance parameters for four of the RED farmlets, 2002-2005 (Clark \& Ledgard 2006).

\begin{tabular}{lccccc}
\hline Farmlet & $\begin{array}{c}\text { Stocking rate } \\
\text { Cows/ha }\end{array}$ & $\begin{array}{c}\text { Target pasture production } \\
\text { t DM/ha/yr }\end{array}$ & $\begin{array}{c}\text { Maize silage fed } \\
\text { t DM/ha/yr }\end{array}$ & $\begin{array}{c}\text { Milksolids } \\
\mathrm{kg} / \mathrm{ha}\end{array}$ & $\begin{array}{c}\text { Milksolids } \\
\mathrm{kg} / \mathrm{total} \text { ha }\end{array}$ \\
\hline 1. Control & 3.0 & 17.5 & 0.0 & 1112 & 1112 \\
2. Standoff & 3.0 & 17.5 & 0.0 & 1080 & 1080 \\
3. Low supplement & 3.8 & 17.5 & 5.5 & 1509 & 1349 \\
4. Mod. supplement & 5.3 & $20.5^{\mathrm{b}}$ & 13.3 & 2175 & 1520 \\
\hline a Includes farmlet area plus area needed to grow maize silage at 24 t DM/ha. & & & \\
b Pasture irrigated on "as required" basis.
\end{tabular}

Clark \& Ledgard 2006, predicted for RED farmlets).

\section{Water use efficiency}

Irrigation is being used increasingly to boost pasture production. Most pasture species have an effective rooting depth of $\sim 60 \mathrm{~cm}$ and the soil in the root zone dries quickly in the absence of rainfall as available water is used by the pasture. Depending on rainfall, irrigation "as needed" usually boosted pasture DM production by $\sim 3000 \mathrm{~kg} /$ ha/yr in the RED study (Clark \& Ledgard 2006). Typical responses from $\mathrm{C} 3$ forage species in the US have been $13-25 \mathrm{~kg} \mathrm{DM} / \mathrm{mm}$ water applied (Guitjens 1990; Jensen et al. 2001). In areas where annual rainfall is low, or on light soils, responses of pasture to irrigation of $2-8 \mathrm{t}$ $\mathrm{DM} / \mathrm{ha} / \mathrm{yr}$ can reasonably be expected in dry years. Maximum production from improved pasture species managed intensively with optimum water and $\mathrm{N}$ applications is unlikely to exceed $20-24 \mathrm{tDM} / \mathrm{ha} / \mathrm{yr}$.

\section{Reducing the environmental impacts of intensification: the case for supplementing pasture with maize silage}

\section{Reducing nitrogen losses}

Feeding a low protein feed such as maize silage $(7.5 \%$ $\mathrm{CP}$ ) in conjunction with high protein pasture dilutes dietary protein content and reduces $\mathrm{N}$ excretion by cows (Table 1). This strategy has been a major focus for improving $\mathrm{N}$ efficiency and reducing $\mathrm{N}$ loss in the $\mathrm{EU}$ (e.g. Aarts et al. 1999; Jarvis et al. 1996; Kebreab et al. 2001). Feeding maize silage can reduce the $\mathrm{N}$ content of urine by $70 \%$ and sharply reduce leaching losses from urine patches (Table 1). Of the total nitrogen excreted in the dung and urine, cows fed maize silage excreted a greater proportion in the dung while cows fed pasture excreted a greater proportion in the urine. However the quantity of $\mathrm{N}$ excreted in dung with a maize diet is relatively small (Ledgard 2006).

Results of the RED trial have been described in detail elsewhere (Clark \& Ledgard 2006; Ledgard et al. 2006a). Pastures for the four relevant treatments (Table 2) received $170 \mathrm{~kg} \mathrm{~N} / \mathrm{ha}$ as urea to boost annual production from $\sim 15$ to $17.5 \mathrm{t} \mathrm{DM} / \mathrm{ha}$. The stand-off treatment used a pad to keep cows off pasture in winter, reducing soil damage and excreta return to pasture during the period when $\mathrm{N}$ leaching was high. Maize silage (grown off-farm) was used to significantly increase production of MS on a total hectare basis.

Quantities of N leached per kg MS, on the farmlets with maize supplements were $21-32 \%$ lower than the all-pasture control (Fig. 1). However, on a whole area basis, $\mathrm{N}$ leached per $\mathrm{kg}$ MS exceeded the control by $7 \%$ and $15 \%$ as the maize silage feeding level increased from 5.5 to $13.3 \mathrm{t} \mathrm{DM} / \mathrm{ha} / \mathrm{yr}$ due to $\mathrm{N}$ leaching on the cropping area. This was based on measured $\mathrm{N}$ leaching of $75 \mathrm{~kg}$ $\mathrm{N} / \mathrm{ha} / \mathrm{yr}$, which is known to be high during the first few years out of pasture. These $\mathrm{N}$ leaching losses under maize were somewhat higher than from other estimates by Pearson (2006). For longer term average estimates, or if maize management practices were aimed at reducing losses (discussed in other sections) by $50 \%$, then the corresponding values would be efficiency gains of 8 and $10 \%$ respectively.

Supplementary use of maize silage contributes to a reduction in gaseous $\mathrm{N}_{2} \mathrm{O}$ losses per unit output from dairy farms. Total $\mathrm{N}_{2} \mathrm{O}$ emissions per hectare from the RED trial maize supplement dairy farm system were $14 \%$ lower than the pasture control (Luo et al. 2006). $\mathrm{N}_{2} \mathrm{O}$ losses in the RED trial from the whole farm system (includes the area used to grow maize and rear replacements) were 7.91, 7.10 and $8.21 \mathrm{~kg} \mathrm{~N}_{2} \mathrm{O} / \mathrm{ha}$ (whole area)/yr for pasture, standoff pasture and low supplementation treatments, respectively. However on a $\mathrm{kg}$ MS basis, $\mathrm{N}_{2} \mathrm{O}$ emissions from the low supplement farmlet were $22 \%$ less than the control pasture farmlet (Luo et al. 2006). $\mathrm{N}_{2} \mathrm{O}$ emissions/ha from the low supplementation system could be reduced significantly if maize silage was fed on a feed pad/stand-off area to avoid pugging soil in wet weather. This merits further study.

\section{Nutrient uptake and responsiveness}

Maize has an effective rooting zone in unimpeded soil of 150-180 cm depth (Kovacs et al. 1995; Grignani et al. 2007). This allows it to capture $\mathrm{N}$ and water from depths 2-3 times greater than most $\mathrm{C} 3$ grasses (e.g. Kristensen $\&$ Thorup-Kristensen 2004). In addition, there is considerable genetic variation among temperate maize hybrids for N uptake (Gallais \& Hirel 2004), suggesting 
Table 3 Water required by maize vs. summer paspalum pasture, Victoria, Australia (Pritchard \& Moran 1987).

\begin{tabular}{lccc}
\hline Crop & $\begin{array}{c}\text { Water required } \\
\text { ML/ha/yr }\end{array}$ & $\begin{array}{c}\text { DM production } \\
\text { t/ha }\end{array}$ & $\begin{array}{c}\text { Water Efficiency } \\
(\mathrm{kg} \mathrm{DM} / \mathrm{mm})\end{array}$ \\
\hline Summer pasture & $9-10$ & $12-15$ & $13-17$ \\
Maize for silage & 7 & 21 & 33 \\
\hline
\end{tabular}

a Paspalum/white clover

that a significant gain in $\mathrm{N}$ capture is likely through breeding. Maize is more responsive to $\mathrm{N}$ than $\mathrm{C} 3$ species, resulting in 40-64 $\mathrm{kg} \mathrm{DM} / \mathrm{kg} \mathrm{N}$ for the initial $30-50 \mathrm{~kg}$ N/ha applied (Binder et al. 2000; Cox \& Cherney 2001). Extrapolating from maize grain trial results (Scharf et al. 2002; K. Clausen, pers. comm. 2004; Grignani et al. 2007; Worku et al. 2007), it would appear that silage responses to $\mathrm{N}$ over the first $50 \mathrm{~kg} \mathrm{~N} /$ ha are in the range of $25-85 \mathrm{~kg} \mathrm{DM} / \mathrm{kg} \mathrm{N}$, for an average of $55 \mathrm{~kg} \mathrm{DM} / \mathrm{kg}$ $\mathrm{N}$. This level of responsiveness is approximately twice that of pasture, due mainly to the high inherent NUE of $\mathrm{C} 4$ grasses than to a reduction in leaching.

\section{Water use efficiency}

C4 species have a high WUE. Studies have shown that maize produced grain yield at $20-36 \mathrm{~kg}$ grain $/ \mathrm{mm}$ water applied (Rhoads \& Bennett 1990), equivalent to a WUE of around 40-72 $\mathrm{kg}$ silage dry matter $/ \mathrm{mm}$. This is almost three times greater than for pasture. Australian data (Table 3 ) endorse this conclusion, even though paspalum is a C4 species.

These data suggest that using maize can significantly improve the WUE of the dairy systems, an important consideration as irrigation expands on dairying land and as climate change progresses.

\section{Managing pasture + maize-based systems for increased output and reduced environmental impact}

\section{Feed pads and their impact on leaching}

Feed pads reduce wastage of feed. They also can double as stand-off areas, reducing pasture pugging and the resulting decrease in pasture utilisation and future yield potential. A large benefit of using stand-off pads in winter is less $\mathrm{N}$ leaching from urine patches since animals urinate less on pastures. Effluent from the pads can be captured and spread uniformly, at a suitable time, over pasture. When high energy, low protein maize silage is fed, effluent $\mathrm{N}$ content is reduced. De Klein and Ledgard (2001) estimated the use of stand-off areas in winter can reduce $\mathrm{N}$ leaching on pasture by $40 \%$, though gaseous ammonia losses were increased. Data from winter standoff and control RED farmlets (Table 2; Fig. 1) suggest that use of stand-off pads in winter can reduce leaching losses by $25 \%$ provided effluent can be dispersed over a sufficiently large area.

\section{Effluent dispersal}

Nutrient surpluses on-farm rise as stocking rates and use of supplements rise and the amounts of dairy effluent increase accordingly (Tables 2, 4). If this effluent is to be returned to farm land at a rate of $150 \mathrm{~kg}$ $\mathrm{N} / \mathrm{ha} / \mathrm{yr}$, for Treatments $1-4$ this will require $18 \%, 40 \%$, $25 \%$ and $33 \%$ of the farm area to be used for effluent dispersal (Ledgard et al. 2006b). Disposing of effluent over $>30 \%$ of the farm area in hilly areas may prove difficult.

Table 4 Nutrient surpluses from the RED trial (external nutrient inputs less outputs as milk and meat) $(\mathrm{kg} / \mathrm{ha} / \mathrm{yr}), 2002-2005$ (Ledgard et al. 2006b).

\begin{tabular}{lcccc}
\hline Farmlet & $\mathrm{N}$ & $\mathrm{P}$ & $\mathrm{K}$ & $\mathrm{Mg}$ \\
\hline 1. Control & 189 & 39 & 51 & 17 \\
2. Stand-off & 189 & 39 & 51 & 17 \\
3. Low supplement & 211 & 46 & 95 & 24 \\
4. Mod. Supplement & 263 & 54 & 159 & 35 \\
\hline
\end{tabular}

Maize silage contains lower levels of $\mathrm{K}$ than pasture, pasture silage and most other forage crops (Holmes et al. 2002). This aids in animal nutrient efficiency and reduces surpluses in the effluent. Because it produces high DM yields, the maize plant has a high demand for nutrients (especially $\mathrm{N}$ and $\mathrm{K}$ ). Effluent from feed pads and dairy sheds with high nutrient contents could be applied preferentially to areas designated for future maize production. Accounting for nutrient content of effluent can reduce fertiliser costs by $\sim \$ 400 /$ ha (D. Bennett, pers. comm. 2007), although there is less flexibility in the timing of nutrient applications using effluent.

\section{Management of nutrients for maize crops}

Maize is easily over-fertilised because it shows no symptoms of excess N. A survey conducted in 2000 indicated that $20 \%$ of maize crops were in this category (FAR 2001). Soil samples used to determine N status prior to sowing are usually taken only in the top 15-30 $\mathrm{cm}$, and do not account for partially leached $\mathrm{N}$ lower in the profile which can be used by maize. The amount of $\mathrm{N}$ supplied by a previous pasture is often underestimated, and farmers respond to visual deficiency symptoms in a few low-fertility areas in the field by increasing application rates. Excess $\mathrm{N}$ fertilisation can be avoided 
by deep soil sampling, use of models such as AmaizeN (Jamieson et al. 2006) to predict $\mathrm{N}$ status following pasture and mineralisation during the season, and the use of optimum plant populations and good weed control. A ryegrass or oat crop sown when maize is harvested in April can remove excess $\mathrm{N}$ (Fowler et al. 2004; Grignani et al. 2007), and frequently does not need additional fertiliser (Densley et al. 2006). Leaching is further reduced by careful timing of $\mathrm{N}$ applications to match peak demands in $\mathrm{N}$ uptake, by splitting applications and ensuring that applied urea is soilincorporated (FAR 2006), and by minimising losses from mineralisation following tillage. The latter can be achieved through no-till, careful selection of tillage equipment, or through the use of minimum or strip tillage techniques (Reicosky 2001). Finally, the risks associated with $\mathrm{N}$ leaching can be decreased by growing maize in non- $\mathrm{N}$ sensitive catchments to allow farm intensification in $\mathrm{N}$-sensitive catchments such as Taupo or Rotorua lakes.

\section{Summary}

Feeding a high-protein all-grass diet can result in high urinary $\mathrm{N}$ losses. Further $\mathrm{N}$ loss occurs through denitrification (especially when soils are waterlogged) and the formation of $\mathrm{N}_{2} \mathrm{O}$, a potent greenhouse gas.

Incorporating maize into well-managed dairying systems can increase MS production, economic farm surplus and return on assets (Hedley et al. 2006). Maize silage provides a dependable high-energy, low-protein feed that complements high protein, lower energy pasture supplies. The RED trial showed that more N per hectare but less $\mathrm{N}$ per kg MS leached from the maize silage-supplemented farmlet than from the all-grass treatment. Feeding maize silage on a feed pad and spreading effluent uniformly over the farm can further reduce $\mathrm{N}$ leaching, particularly when the pad is also used for standing off or feeding in the winter. Pasture supplemented with maize silage also emitted less $\mathrm{N}_{2} \mathrm{O}$ than the all-grass systems. The increase in maize dry matter production in response to added $\mathrm{N}$ and water, where production is constrained by these inputs, can be 2-3 times greater than that of pasture - a very significant benefit as prices for both inputs steadily increase.

Managing maize silage to maintain its low environmental impact requires the use of a feed pad and care in soil management, determining soil $\mathrm{N}$ status at planting and correct timing of $\mathrm{N}$ applications. Where maize is purchased off-farm, feed pad effluent can substitute for purchased fertilisers.

We conclude that maize silage, when properly managed, can reduce the environmental impact of intensive all-grass systems, especially when $\mathrm{N}$ application is matched to crop needs, reduced tillage, strip tillage or minimum is used and the crop is fed on a feed pad.

\section{REFERENCES}

Aarts, H.F.M.; Habekotte, B.; Hilhorst, G.J.; Koskamp, G.J.; Van der Schans, F.C.; De Vries, C.K. 1999. Efficient resource management in dairying on sandy soil. Netherlands Journal of Agricultural Science 47: 153-167.

Binder, D.L.; Sander, D.H.; Walters, D.T. 2000. Maize response to time of nitrogen application as affected by level of nitrogen deficiency. Agronomy Journal 92: 1228-1236.

Cox, W.J.; Cherney, D.J.R. 2001. Row spacing, plant density, and nitrogen effects on corn silage. Agronomy Journal 93: 597-602.

Clark, D.; Ledgard, S. 2006. Environmental messages from the RED trial. Dexcelink 2007 (www.dexcel.co.nz). 2 pp.

Densley, R.J.; Austin, G.M.; Williams, I.D.; Tsimba, R.; Edmeades, G.O. 2006. Maize silage and winter crop options to maximize drymatter and energy for NZ dairy systems. Proceedings of the New Zealand Grassland Association 68: 193-197.

de Klein, C.A.M; Ledgard, S.F. 2001. An analysis of environmental and economic implications of nil and restricted grazing systems designed to reduce nitrate leaching from New Zealand dairy farms. I. Nitrogen losses. New Zealand Journal of Agricultural Research 44: 201-215.

Easton, S.; Amyes J.M.; Cameron, N.E.; Green, R.B.; Kerr, G.A.; Norriss, M.G.; Stewart, A.V. 2002. Pasture plant breeding in New Zealand: where to from here? Proceedings of the New Zealand Grassland Association 64: 173-179.

EPA. 2007. Emission facts: metrics for expressing greenhouse gas emissions: carbon equivalents and carbon dioxide equivalents. (http://www/epa.gov.otaq/ climate/).

FAR. 2001. Nitrate leaching. FAR Arable Maize Update No. 29. (http://www.far.org.nz). 2 pp.

FAR. 2006 Early season leaching of $\mathrm{N}$ in maize paddocks. FAR Arable Maize Update No. 36. (http:// www.far.org.nz). 3 pp.

Fowler, C.J.E.; Condron, L.M; McLenaghen, R.D. 2004. Effects of green manures on nitrogen loss and availability in an organic cropping system. New Zealand Journal of Agricultural Research 47: 95-100.

Gallais, A.; Hirel, B. 2004. An approach to the genetics of nitrogen use efficiency in maize. Journal of Experimental Botany 55: 295-306.

Grignani, C.; Zavattoro, L.; Sacco, D.; Monaco, S. 2007. Production, nitrogen and carbon balance of maizebased forage systems. European Journal of Agronomy 
26: 442-453.

Guitjens, J.C. 1990. Alfalfa. pp. 537-568. In: Irrigation of Agricultural Crops. Eds. Stewart, B.A; Nielsen, D.R.. Agronomy No. 30, American Society of Agronomy, WI.

Harris, S.L.; Thom, E.R.; Clark, D.A. 1996. Effect of high rates of nitrogen fertiliser on perennial ryegrass growth and morphology in grazed dairy pasture in northern New Zealand. New Zealand Journal of Agricultural Research 39: 159-169.

Hedley, P.; Kolver, E.; Glassey, C.; Thorrold, B.; van Bysterveldt, A.; Roche, J.; Macdonald, K. 2006. Achieving high performance from a range of farm systems. pp. 147-166. In: Proceedings of the 2006 Dairy3 Conference 4.

Hoekstra, N.J.; Schulte, R.P.O.; Struik, P.C.; Lantinga, E.A. 2007. Pathways to improving the N efficiency of grazing bovines. European Journal of Agronomy 26: 363-374.

Holmes, C.W.; Brookes, I.M.; Garrick, D.J.; MacKenzie, D.D.S.; Parkinson, T.J.; Wilson, G.F. 2002. Nutrition: Food intake and nutritive value. pp. 263-294. In: Milk production from pasture. Ed. Swain, D. Massey University, Palmerston North, N.Z.

Jarvis, S.C.; Wilkins, R.J.; Pain, B.F. 1996. Opportunities for reducing the environmental impact of dairy farming managements: a systems approach. Grass and Forage Science 51: 21-31.

Jamieson, P.D.; Li, F.Y.; A. Pearson. 2006. An AmaizeN first year: report on SFF project 05/096 Nitrogen management for sustainable maize production. Crop and Food Research Confidential Report No. 1700. NZICFR, Christchurch.

Jensen, R.N.; Clark, D.A.; Macdonald, K.A. 2005. Resource Efficient Dairying trial: measurement criteria for farm systems over a range of resource use. Proceedings of the New Zealand Grassland Association 67: 47-52

Jensen, K.B.; Asay, K.H.; Waldron, B.L. 2001. Dry matter production of orchardgrass and perennial ryegrass at five irrigation levels. Crop Science 41: 479487.

Kebreab, E.; France, J.; Beever, D.E.; Castillo, A.R. 2001. Nitrogen pollution by dairy cows and its mitigation by dietary manipulation. Nutrient Cycling in Ecosystems 60: 275-285.

Kovacs, G.J.; Nemeth, T.; Ritchie, J.T. 1995. Testing simulation models for the assessment of crop production and nitrate leaching in Hungary. (http:// www.taki,iif.hu/cikkek/agrisys.doc). 13 pp.

Kristensen, H.L.; Thorup-Kristensen, K. 2004. Root growth and nitrate uptake of three different catch crops in deep soil layers. Soil Science Society of America Journal 68: 529-537.
Ledgard, S.; Menneer, J.C. 2005. Nitrate leaching in grazing systems and management strategies to reduce losses. pp. 79-92. In: Occasional Report No. 18. Eds. Currie, L.D.; Hanly J.A. Fertiliser and Lime Research Centre, Massey University.

Ledgard, S. 2006. Nitrogen management - why is it important and what can we do about it? pp 23-31. In: Proceedings of the 2006 Dairy3 Conference 4.

Ledgard, S.; Sprosen, M.; Judge, A.; Lindsay, S.; Jensen, R.; Clark, D.; Luo, J. 2006a. Nitrogen leaching as affected by dairy intensification and mitigation practices in the Resource Efficient Dairying (RED) trial. pp. 263-268. In: Occasional Report No. 19. Eds. Currie, L.D.; Hanly J.A. Fertiliser and Lime Research Centre, Massey University.

Ledgard, S.; Menneer, J.; Boyes, M.; Jensen, R.; Clark, D. 2006b. Effects of dairy intensification in the Resource Efficient Dairying trial on soil physics, nutrient flows and fertiliser and lime requirements. pp. 281-289. In: Occasional Report No. 19. Eds. Currie, L.D.; Hanly J.A. Fertiliser and Lime Research Centre, Massey University.

Luo, J.; Ledgard, S.; Lindsay, S. 2005. Nitrous oxide emission from fertiliser urea. pp. 209-219. In: Occasional Report No. 18. Eds. Currie, L.D.; Hanly J.A. Fertiliser and Lime Research Centre, Massey University.

Luo, J.; Ledgard, S.; Lindsay, S. 2006. Nitrous oxide emissions from dairy farm systems. pp. 269-280. In: Occasional Report No. 19. Eds. Currie, L.D.; Hanly J.A. Fertiliser and Lime Research Centre, Massey University.

Pearson, A. 2006. N leaching under maize. pp.1-6. In: Proceedings of the Foundation for Arable Research Maize Conference. Foundation for Arable Research, Lincoln, NZ

Pritchard, K.; Moran, J. 1987. Maize for fodder - a guide to growing, conserving and feeding irrigated maize in northern Victoria. Technical Report Series No 146. Victorian Department of Agriculture and Rural Affairs. Kyabram.

Quin, B.F.; Blennerhassett, J.D.; Zaman, M. 2005. The use of urease inhibitor-based products to reduce nitrogen losses from pasture. pp. 288-304. In: Occasional Report No. 18. Eds. Currie, L.D.; Hanly J.A. Fertiliser and Lime Research Centre, Massey University.

Reicosky D.C. 2001. Effects of conservation tillage on soil organic carbon dynamics: field experiments in the US corn belt. pp 481-485. In: Sustaining the Global Farm. Eds. Stott, D.E.; Mohtar, R.H.; Steinhardt, G.C. http://topsoil.nserl.purdue.edu/nserlweb/isco99/pdf/ ISCOdisc/Sustaining TheGlobalFarm/P002Reicosky.pdf 
Rhoads, F.M.; Bennett, J.M. 1990. Corn. pp. 569-596. In: Irrigation of Agricultural Crops. Eds. Stewart, B.A; Nielsen, D.R. Agronomy No. 30, American Society of Agronomy, WI.

Scharf, P.C.; Wiebold, W.J.; Lory, J.A. 2002. Corn yield response to nitrogen fertiliser timing and deficiency level. Agronomy Journal 94: 435-441.

Van Der Nagel, L.S.; Waghorn, G.C.; Forgie, V.E. 2003.
Methane and carbon emissions from conventional pasture and grain-based total mixed rations for dairying. Proceedings of the New Zealand Society of Animal Production 63: 128-132.

Worku, M.; Banziger, M.; Erley, G.S.; Friesen, D.; Diallo, A.O.; Horst W.J. 2007. Nitrogen uptake and utilization in contrasting nitrogen efficient tropical maize hybrids. Crop Science 47: 519-528. 